\title{
MEDIATION ROLE OF AUDIT GOING CONCERN OPINION ON CORRELATION OF AUDIT TENURE AND MARKET PERFORMANCE
}

\author{
Annisa Rahmawati ${ }^{1 *}$, Arsono Laksmana ${ }^{2}$, and Dian Agustia ${ }^{3}$ \\ 1,2,3 Universitas Airlangga, Surabaya, Indonesia
}

\begin{abstract}
This study aims to obtain empirical evidence of the mediating role of going concern opinion audit on the relationship of audit tenure with company market performance. This research is explanatory. The subjects in this study were companies listed on the Indonesia Stock Exchange from 2007 to 2017. The samples in this study were 245 companies. The type of data used is quantitative data. The statistical analysis method uses path analysis with SPSS 13. The results of the study show that going concern audit opinion has a significant negative relationship in mediating audit tenure and company market performance. These results indicate that going concern audit opinion has information that is useful for users' financial data to make financial decisions. Keywords: Audit Tenure, Going Concern Audit Opinion, Market Performance
\end{abstract}

\section{INTRODUCTION}

The audit opinion is an observable result of a series of audit processes, which are issued in the name of the public accountant's office in line with the issuance of audited client financial statements. (Francis, 2011). Research on audit opinion is important because audit opinion is an auditor's communication tool that presents findings during the audit process and many parties rely on that information. (Arens, Elder, \& Mark, 2014).

In the audit opinion, there is an explanation of information about whether financial statements are presented fairly (Geiger \& Raghunandan, 2002; Hay, Knechel, \& Willekens, 2014). Audit opinion for a company can show that the auditor has a message relating to the going concern status of the company concerned. (Gibson, 2013).

In carrying out audits of financial statements, the auditor must provide confidence in the financial statements, that financial statements are free of material misstatements, whether caused by fraud (fraud) or errors. At the end of the audit phase, the auditor explains whether the financial statements have been fairly prepared in all material matters. Therefore audit opinion is important information because many users depend on the information described in the report. (Arens et al., 2014).

An explanation paragraph about going concern is useful information. Previous studies related to the going concern explanatory paragraph have seen the relationship between stock price reactions and going-concern audit opinions. Company stock returns are used to build future return expectations. Return is expected to be compared with the actual return around the period when the going concern audit opinion is released. If the actual return differs significantly from the expected return, it will illustrate that the going-concern audit opinion brings information that is useful to the market. As explained in a study conducted by Dodd (1984), Fleak (1994), Soltani (2000), and O'Rilley (2009) that audit opinions that contain an entity's going concern opinion will negatively affect return stock. On the other hand, if the actual return value does not differ significantly from the expected return, the business continuity audit opinion is considered not to provide useful information for investors. As explained in a study conducted by Martinez et al (2004) and Tahinakis et al (2016), audit opinions do not have a significant effect on stock returns.

* Corresponding author. Email address : rahmawaty.annisa@gmail.com 
Audit quality can be measured from the opportunity that the auditor will issue a going concern opinion, assuming that audit quality will decrease if the auditor does not issue an opinion about the continuity of the business when the company goes bankrupt. (Knechel \& Vanstraelen, 2007)

Audit tenure is the length of the relationship between the client and the auditor that can be measured by the number of years the auditor conducts a client audit (V. E. Johnson, Khurana, \& Reynolds, 2002; Myers et al., 2003). The longer the auditor's tenure, the quality of audited financial statements will increase because the auditor's understanding of the client's business and accounting system will be better. Therefore investors will feel less uncertainty in their investment decisions (Ghosh \& Moon, 2005; $\mathrm{Su}, \mathrm{Zhao}, \&$ Zhou, 2015). In making investment decisions, investors pay attention to audit tenure as a factor that influences stock return movements. Longer audit tenure can improve the quality of audit work and hence stock returns will be stable. (Jorjani \& Safari Gerayeli, 2018). This statement is supported by previous research conducted by Callen and Fang (2016) which explains that auditor tenure is negatively related to the risk of falling stock prices for the following year. (Callen \& Fang, 2016)

The results of this study show three features including:

1) Audit tenure has a significant positive effect on the going-concern audit opinion.

2) Going concern audit opinion has a significant negative effect on market performance.

3) Audit tenure has a significant positive effect on market performance; and

4) Going concern audit opinion has a significant negative effect on mediating the relationship between audit tenure and company market performance.

The contribution of this study is to provide empirical evidence that the longer the audit tenure does not reduce the tendency of auditors to provide going concern audit opinions to clients. Longer audit tenure is seen as an influence that can increase the knowledge and technical capabilities of the auditors concerned so that it can increase market confidence demonstrated by increasing market performance along with increasing audit tenure. When an auditor with long audit tenure publishes a going concern going audit opinion then the market will give a negative reaction to that information which is indicated by a significant negative influence of going concern audit opinion in mediating the relationship between audit tenure to market performance. This shows that the going concern audit opinion does have information that is beneficial for users of financial data to make financial decisions, it is used by the market as the main guideline for making financial decisions that lead to negative market reactions when a going concern opinion is issued by an auditor who has a tenure audit length. This is a reflection of the confidence of users of information that the audit has been carried out in a reasonable manner.

\section{LITERATURE REVIEW}

Auditors have an important role in building public trust in the published financial statements of the company. This statement is explained in one audit theory called "Inspired Confidence Theory" (1932) which is a theory that explains that auditors have an important role in building public trust in the company's financial statements that are published. An audit is a process that is believed enable to be provided in the financial statements presented by management related to the condition of the company which consists of the use of resources owned by the company concerned. (Limperg, 1985). Inspired Confidence Theory explains two features that influence the independent auditor's opinion, namely the technical ability and individual characteristics of the auditor concerned. Technical capabilities are built by elements of experience, while the individual characteristics of auditors consist of empathy, responsiveness, and assurance (Brunelli 2018).

Audit tenure is the length of the relationship between the client and the auditor that can be measured by the number of years the auditor carries out an audit on the client (Myers et al., 2003). In the context of an audit, audit experience can be obtained from 


\section{MEDIATION ROLE OF AUDIT GOING CONCERN OPINION ON CORRELATION OF AUDIT TENURE AND MARKET PERFORMANCE}

the interaction between the auditor and his client which can be seen from the audit tenure.

The audit opinion is a result that can be observed from a series of audit processes, which are issued in the name of an accountant's office in line with the issuance of audited client financial statements where the information can affect clients and users of financial statement information which ultimately lead to economic consequences (Tritschler, 2013 )

In the audit opinion, there is an explanation of information about whether financial statements are presented fairly (Geiger \& Raghunandan, 2002; Hay, Knechel, \& Willekens, 2014). Additionally the audit opinion for a company can indicate that the auditor has a message relating to the going concern status of the company concerned. (Gibson, 2013). Going concern audit opinion is one of the independent auditor's communication tools to the public. Blay (2011) explains that markets interpret audit opinions with going concern paragraph as important risk communication. Communication is part of the information that is published to the public when the company in question publishes an annual report. (Blay et al., 2011). Going concern opinion will bring economic consequences, especially for company shareholders, namely the company's market performance (Brunelli, 2018). Market performance is a securities or asset behavior in the market place (O.B. Dictionary). The most common way to measure market performance from a company is to use the return received by the shareholders (stock return). (Koller et al, 2010). If in the stock market the number of buyers of certain shares amounts to more than the number of sellers, then the stock price will rise along with demand (Soenen, 2003). The purpose of this study is to obtain empirical evidence of the role of going-concern audit opinion in mediating the relationship of audit tenure with market performance.

\section{HYPOTHESIS DEVELOPMENT}

\section{Audit Tenure and Going Concern Audit Opinion}

Based on the Theory of Inspired Confidence Theory (1932), audit opinion is considered to be able can give confidence to the owner of the company because the opinion is composed by an independent party that has no affiliation with the company. Based on Inspired Confidence Theory, audit tenure is an important aspect that affects company market performance because audit tenure is a representation of the experience that the auditor has with clients in similar types of industries. A longer audit tenure means a longer relationship between the auditor and his client, and the more technical knowledge the auditor has regarding the client's business cycle. This theory also explained that the presentation of information in an audit opinion will depend on the technical capabilities possessed by the auditor concerned and in the end the audit opinion provided will be a source of information for the owner of the company in the decision making process. (Limperg, 1985)

As explained above, audit tenure is one element of knowledge in the realm of experience. Through adequate experience, auditors can have intensive knowledge that comes from a series of audit tasks that have been carried out. (Bonner \& Lewis, 1990). Experience can come from the interaction between the auditor and his client which can be seen from the audit tenure. The quality of audit work can increase along with the audit tenure period where auditors can acquire a better understanding of client systems, client businesses, and industrial environments (Dunham, 2002). Audit tenure can be measured by the number of years in which the company uses the services of the auditor concerned (Myers et al., 2003). A brief audit tenure can reduce the tendency to have specific knowledge relating to clients. Knowledge gained from the audit process for certain clients can be used to audit clients with similar businesses (Hay et al., 2014).

Some previous studies explained that a long audit tenure did not reduce audit quality by reducing the tendency to provide going-concern audit opinions (Geiger \& Raghunandan, 2002; Jackson et al., 2008; Knechel \& Vanstraelen, 2007)

H1: Audit tenure has a positive relationship with going-concern audit 


\section{Going Concern Audit Opinion and Market Performance}

Inspired Confidence Theory (1932) explained that the audit was carried out to build public trust. The trust of the community rests on audit opinions from the results of the tests carried out during the audit process in progress (Limperg, 1985). The audit opinion is a result that can be observed from a series of audit processes, where the information can affect clients and users of financial statement information which ultimately lead to economic consequences (Francis, 2011)

Based on the explanation of Inspired Confidence Theory (1932), when the independent auditor has doubts about the company's ability to continue its business (going concern), the auditor must disclose such uncertainty in the audit opinion. In an efficient market, returns from company shares will be influenced by the expectations of users of information relating to the company's prospects. When there is unexpected information presented in the audit report, it can have an impact on the price of the overall security (Brunelli, 2018)

Previous research that examined the relationship of going concern audit opinion and stock prices was presented by Fleak (1994), who explained that there was a significant negative relationship between going concern and stock price movements (Fleak \& Wilson, 1994). Soltani (2000) also researched the relationship of going concern audit opinion to stock prices. The results of this study are consistent with the research of Fleak (1994) which shows a significant negative relationship between stock abnormal returns and going-concern audit opinions (Soltani, 2000).

H2: Going concern audit opinion has a negative relationship with company market performance

\section{Audit Tenure and Market Performance}

Inspired Confidence Theory (1932) explained that the audit was carried out to build public trust. The audit function itself leads to public trust. The trust of the community is built by their views on the auditor's ability in conducting audits. In the context of an audit, the experience is an element that builds the capabilities possessed by the auditor. The experience gained by auditors from conducting audits in various companies that have been handled by them can be a provision to handle companies in similar industries (Limperg, 1985).

Audit tenure is the length of the relationship between the client and the auditor that can be measured by the number of years the auditor audits the client (Myers, et al 2003). Inspired Confidence Theory (1932) has explained that auditor experience can be obtained from the interaction between auditors and audited companies. A longer audit tenure can improve the auditor's understanding of the client's business and accounting system. Therefore investors will feel less uncertainty in their investment decisions (Ghosh \& Moon, 2005; Su et al., 2015). In making investment decisions, investors pay attention to audit tenure as a factor that influences the movement of market performance. Longer tenure audits can improve the quality of audit work and therefore market performance will be stable. (Jorjani \& Safari Gerayeli, 2018).

The quality of audit work will increase along with the audit tenure period where auditors can obtain a better understanding of the client system, client business and industrial environment (Dunham, 2002). The correlation of audit tenure in company market performance as measured by stock returns has been discussed in previous studies as explained by Gosh and Moon (2005) suggested that longer audit tenure is considered to improve the quality of information presented, shown by the increase in the company's stock rating. Ghosh and Moon's (2005) statement is supported by the $\mathrm{Su}$ (2015) study which explains that the long audit tenure is considered capable of increasing information credibility so that it can increase stock prices ( $\mathrm{Su}$ et al., 2015).

H3: Tenure audit has a positive relationship with company market performance.

Audit Tenure and Market Performance Audit through Going Concern Audit Opinion

Inspired Confidence Theory (1932) explains that audits are carried out to build public trust. (Limperg, 1985). The audit opinion is the only result of the audit process 


\section{MEDIATION ROLE OF AUDIT GOING CONCERN OPINION ON CORRELATION OF AUDIT TENURE AND MARKET PERFORMANCE}

that can be observed, where the report can affect clients and users of financial statement information which ultimately drives economic consequences (Tritschler, 2013). Inspired Confidence Theory, also explained that an audit opinion is influenced by the technical capabilities possessed by the auditor concerned and this can be reflected in the size of the public accounting firm, audit tenure (Limperg, 1985).

Audit tenure can affect company market performance because it is considered to reduce information asymmetry that can increase the credibility of financial statement information needed by investors in making investment decisions that ultimately affect company market performance. A longer audit tenure is a benchmark of the abilities and knowledge possessed by the auditor concerned and more able to be able to reveal the actual financial condition of the company, especially when there is a problem of business continuity in the company concerned. (Dunham, 2002; Knechel \& Vanstraelen, 2007). Hence it can be concluded that when an accountant office with an audit tenure issued a longer paragraph going concern explanation, the market will perceive this as negative information that can reduce the company market performance.

H4: Going concern audit opinion has a negative role in mediating the correlation between the tenure of the audit and the company's market performance.

\section{RESEARCH METHODOLOGY}

The research approach used in this study is a quantitative approach. The approach used to test the research hypothesis is to use Path Analysis using multiple regression, which is a technique that can be used to analyze the relationship between the dependent variable and several dependent variables (Hair, Black, \& Babin, 2010). The subjects of this study were all companies listed on the Indonesia Stock Exchange from 2007 to 2017. The size of the sample of this study was 245 which had a negative trend in financial ratios so far. The aim of this research is the role of going concern audit opinion in mediating audit tenure and company market performance.

The multiple linear regression equations in this study are as follows:

$$
\begin{gathered}
G O=a_{1}+b_{1} A T+b_{2} \text { COMPSIZE }+b_{3} L E V+b_{4} A G E+b_{5} R O E+\varepsilon \\
M P=a_{2}+b_{6} A T+b_{7} G O+b_{8} C O M P S I Z E+b_{9} L E V+b_{10} A G E+b_{11} R O E+\varepsilon
\end{gathered}
$$$$
M P=a_{3}+b_{12} A T+b_{13} C O M P S I Z E+b_{14} L E V+b_{15} A G E+b_{16} R O E+\varepsilon
$$

Information :

$\begin{array}{ll}\text { GO } & =\text { Going Concern Audit Opinion } \\ \text { MP } & =\text { Market Performance } \\ \text { AT } & =\text { Audit Tenure } \\ \text { CompSize } & =\text { Company Size } \\ \text { Lev } & =\text { Leverage } \\ \text { Age } & =\text { Company Age } \\ \text { ROE } & =\text { Return on Equity }\end{array}$

\section{RESULT}

\section{Correlation Analysis}

The variables used in this study are independent variables namely audit tenure (AT) size, intervening variables going concern audit opinion (GO), dependent variables namely market performance (MP) and firm size control variables (COMP SIZE), company age (AGE), leverage (LEV) and return on equity (ROE). The analysis carried out in this study was used to determine the level of the interrelation of the variables that were used in the path of analysis. The results of the analysis can be presented as follows: 
Correlation Table Research Variables

\begin{tabular}{ccccc}
\hline Variable & MP & AFS & AT & GO \\
\hline MP & 1 & & & \\
AT & $0.257^{* *}$ & $0.586^{* *}$ & 1 & \\
GO & $0.247^{* *}$ & $0.627^{* *}$ & $0.637^{* *}$ & 1 \\
\hline
\end{tabular}

**Sig Level 1\%

The results of the correlation analysis that occur between the main variables in the research model have concluded that there is a direct and significant closeness at the level of $1 \%$ so that these variables are feasible to be used in path analysis.

\section{Path Analysis}

Referring to the research conducted by Dawn Iacobucci (2012) path analysis with the mediation of categorical variables is done through estimating three regression models as follows:

I. Effect of $\mathrm{X}$ (exogenous) on $\mathrm{Y}$ (endogenous) / $\mathrm{X} \rightarrow \mathrm{Y}$ is performed using multiple linear regression analysis.

II. The influence of $\mathrm{X}$ (exogenous) on $\mathrm{Z}$ (intervening) / $\mathrm{X} \rightarrow \mathrm{Z}$ is done using logistic regression analysis.

III. The influence of $\mathrm{X}$ (exogenous) and $\mathrm{Z}$ (intervening) on $\mathrm{Y}$ (endogenous) / $\mathrm{X}$ \& $\mathrm{Z} \rightarrow \mathrm{Y}$ was also carried out using regression analysis.

From the explanation above, in estimating the path in models I and III it is necessary to test the classical assumptions of the regression model, while in model II the feasibility of the logistic model is tested.

\section{Hypothesis Testing}

Path Analysis Estimation Results Table

\begin{tabular}{cccc}
\hline Variabel & $\begin{array}{c}\text { Model I } \\
(\mathrm{Y} \rightarrow \mathrm{GO})\end{array}$ & $\begin{array}{c}\text { Model II } \\
(\mathrm{Y} \rightarrow \mathrm{MP})\end{array}$ & $\begin{array}{c}\text { Model III } \\
(\mathrm{Y} \rightarrow \mathrm{MP})\end{array}$ \\
\hline \multirow{2}{*}{$\mathrm{C}$} & -1.624 & 0.054 & 0.061 \\
& $(0.407)$ & $(0.947)$ & $(1.074)$ \\
AT & $0.837^{* *}$ & $0.006^{* *}$ & $0.008^{* *}$ \\
& $(30.962)$ & $(2.596)$ & $(3.243)$ \\
GO & & & -0.025 \\
& & & $(-2.058)$ \\
COMPSIZE & -0.047 & -0.003 & -0.003 \\
& $(0.253)$ & $(-1.368)$ & $(-1.421)$ \\
LEV & -0.011 & 0.000012 & -0.000022 \\
& $(0.322)$ & $(0.480)$ & $(-0.870)$ \\
ROE & $2.570^{*}$ & 0.029 & 0.035 \\
& $(3.897)$ & $(1.940)$ & $(2.311)$ \\
AGE & -0.019 & -0.000026 & -0.0001 \\
Adj R Squared & $(1.460)$ & $(-0.069)$ & $(-0.333)$ \\
\hline
\end{tabular}

Based on the summary results of the path analysis estimation results can be explained the results of proving the research hypothesis as follows:

1. Hypothesis I 


\section{MEDIATION ROLE OF AUDIT GOING CONCERN OPINION ON CORRELATION OF AUDIT TENURE AND MARKET PERFORMANCE}

Hypothesis I of the study states that audit tenure has a positive effect on going concern audit opinion. This hypothesis is proven through the logistic regression model (Model I) which obtained a Wald value of 23,069 with a significance of 0,000. Based on the logistic regression coefficient that is positive and the significance value of Wald shows that the influence of audit tenure on going concern audit opinion is positive and significant with a significance value of $0,000<0.05$. Thus the hypothesis I research can be proven true.

2. Hypothesis II

Hypothesis II of the study states that going concern audit opinion has a negative effect on market performance. This hypothesis is proven through Model III which obtained the $t$ value of -2.058 with a significance of 0.041 . Based on the negative $t$ value and the significance value of $t$ arithmetic the influence between going concern audit opinion on market performance is negative and significant with a significance value of 0.041 $<0.05$.

\section{Hypothesis III}

Hypothesis III of the study states that audit tenure has a positive effect on market performance. This hypothesis is proven through Model III which obtained the t value of 4.501 with a significance of 0.000 . Based on the positive value of $t$ arithmetic and the significance value of $t$ arithmetic the influence of audit tenure on market performance is positive and significant with a significance value of $0,000<0.05$.

4. Hypothesis IV

The mediation test in this study was based on the theory presented by Baron \& Kenny (1986) with the results of testing in the logistic regression analysis indicating that the influence of the size of the public accounting firm on going concern opinion was significant (AT AT GO: $0.000<0.05$ ). In other models, multiple linear regression analysis concludes that going concern opinion has a significant influence on market performance (GO $\rightarrow$ MP: $0.041<0.05$ ). Thus, based on the theory of Baron \& Kenny (1986), it can be concluded that there is an influence between the size of the public accounting firm on market performance through going concern audit opinion. The mediating nature of the relationship between the size of the public accounting firm against market performance through going concern opinion is concluded to be partial mediation. This is because the results of testing the influence between audit tenure variables directly on market performance in the multiple linear regression model are significant than in the linear regression Model III. The results after entering the going concern opinion mediation variable also remain significant (AT $\rightarrow$ MP: $0.001<0.05$ ).

\section{DISCUSSION}

Discussion of the results of hypothesis testing on the overall pathway model can be summarized as follows:

1. The first hypothesis is that the audit tenure has a significant positive effect on the proven concern audit opinion with a significance level of $<0.05$. The results of statistical analysis in this study support the explanation of Inspired Confidence Theory (1932) that to carry out audits properly, adequate technical capabilities are needed (Limperg, 1985). Experience (experience) is an element in technical capabilities that affects the quality of audit work. The experience of auditors from companies that they have handled can improve the technical capabilities they possess. In the context of an audit, the experience can be obtained from the interaction between the auditor and his client. The length of the auditor's interaction with his client is called audit tenure. A longer tenure audit can improve the auditor's understanding of the client's business and accounting system. Auditors with a longer audit tenure, are perceived to be able to provide good quality audit work. An audit is considered to have good quality if the auditor concerned is able to express the company's true financial condition, especially when there is a problem of going concern (Ghosh \& Moon, 2005; Knechel \& Vanstraelen, 2007). The 
results of testing the first hypothesis in this study support the research of Geiger and Raghunandan (2002), Jackson et al (2008) and Knechel Vanstraelen (2007) which describe a positive relationship between audit tenure and going-concern audit opinion. A significant positive relationship between audit tenure and going concern audit opinion means that a longer audit tenure will enable the auditor to have better knowledge regarding the client's condition, and therefore will increase the likelihood of the issuance of going concern audit opinion on companies experiencing financial difficulties.

2. The second hypothesis is that going concern audit opinion has a significant negative effect on proven market performance with a significance level of $<0.05$. The results of the statistical analysis in this study support the explanation of Inspired Confidence Theory (1932) that the audit was conducted to build public trust. The trust of the community rests on audit opinions from the results of the tests carried out during the audit process in progress (Limperg, 1985). The audit opinion is a result that can be observed from a series of audit processes, where the information can affect clients and users of financial statement information which ultimately leads to economic consequences (Francis, 2011). When an independent auditor has doubts about the company's ability to continue, the auditor must disclose this in the audit opinion. The issuance of going-concern audit opinion reacts to companies that have experienced financial difficulties. Information that was previously private to the company then moves into the public arena. This information can trigger a different reaction among parties interested in the company, one of which is shareholders. In an efficient market, the company's market performance will be influenced by the expectations of information users on the company's prospects. When there is unexpected information presented in an audit opinion, it can have an impact on the company's overall market performance. (Brunelli, 2018). The results of testing the second hypothesis support the research of Dodd (1984), Fleak (1994), Soltani (2000) and O'Rilley (2009) which describe the existence of a negative relationship between going-concern opinions and company market performance. This means that going-concern audit opinion valuable to users of financial information. Users of information view that goingconcern audit opinions imply that the company is experiencing sustainability problems so that it lowers expectations of the company's prospects and ultimately lowers the company's market performance.

3. The third hypothesis is that audit tenure has a significant positive effect on proven market performance with a significance level of $<0.05$. The results of the statistical analysis in this study support the explanation of Inspired Confidence Theory (1932) that the audit was carried out to build public trust. The audit function itself leads to public trust. The trust of the community is built by their views on the auditor's ability in conducting audits. In the context of an audit, the experience is an element that builds the capabilities possessed by the auditor. The experience gained by auditors from conducting audits in various companies that have been handled by them can be a provision to handle companies in similar industries (Limperg, 1985). The auditor's experience can be obtained from the interaction between the auditor and the audited company. The period of interaction between the auditor and the company is called audit tenure. A longer audit tenure can improve the auditor's understanding of the client's business and accounting system. Therefore investors will feel lower uncertainty in their investment decisions reflected in stable market performance (Dunham, 2002; Ghosh \& Moon, 2005; Jorjani \& Safari Gerayelo, 2018; Su et al., 2015). The results of testing the third hypothesis support the research by Su et al (2015) and Callen Fang (2016) show a positive relationship between audit tenure to company market performance. The positive relationship between audit tenure and market performance shows that users of financial information believe that the information presented by auditors with longer audit tenure is reliable information. When financial information users have confidence 


\section{MEDIATION ROLE OF AUDIT GOING CONCERN OPINION ON CORRELATION OF AUDIT TENURE AND MARKET PERFORMANCE}

in the information, the company will be more in demand and ultimately can improve the company's market performance.

4. The fourth hypothesis is that audit tenure has a significant negative effect on market performance through going-concern audit opinion is proven with a significance level of $<0.05$. Inspired Confidence Theory explains that audits are carried out to build public trust. (Limperg, 1985). The audit opinion is the only result of the audit process that can be observed, where the report can affect clients and users of financial statement information which ultimately drives economic consequences (Tritschler, 2013). Inspired Confidence Theory also explains that giving an audit opinion is influenced by the technical capabilities of the auditor concerned which can be reflected in, audit tenure (Limperg, 1985). Audit tenure is something that can affect the company's market performance because it is assessed to reduce information asymmetry that can increase the credibility of financial statement information needed by investors in making investment decisions that ultimately affect the company's market performance. Longer tenure audit is a measure of the ability and knowledge possessed by the auditor concerned and is better able to reveal the true financial condition of the company, especially when there is a going concern problem in the company concerned. (DeAngelo, 1981; Dunham, 2002; Knechel \& Vanstraelen, 2007). Hence it can be concluded that when an accountant's office with an audit tenure that publishes a longer opinion with the going concern explanatory paragraph, the market will also believe this as negative information that can reduce the market performance of the company concerned.

\section{CONCLUSION}

Based on the results of the research and discussion previously explained, the conclusions that can be drawn from this study are: audit tenure has a positive and significant impact on the company's market performance with a significance level of $5 \%$. From these results, it can be concluded that the market views audit tenure as a benchmark that a longer audit tenure, will enable auditor to be better able to carry out the audit work because he has greater knowledge than the auditor with a shorter audit period. But when the auditor issues a going-concern audit opinion, the market will respond to this as negative information which ultimately reduces the company's market performance. The negative response is the result of market confidence in the auditor's work. Because the market believes in the results of the auditor's work, then when the auditor issues an audit opinion, the market will respond to this as negative information which ultimately lowers the company's market performance.

\section{References}

Arens, A. A., Elder, R. J., \& Mark, B. (2014). Auditing and assurance services: an integrated approach: Boston: Prentice-Hall.

Blay, A. D., Geiger, M. A., \& North, D. S. (2011). The auditor's going-concern opinion as a communication of risk. AUDITING: A Journal of Practice \& Theory, 30(2), $77-102$.

Bonner, S. E., \& Lewis, B. L. (1990). Determinants of auditor expertise. Journal of Accounting Research, 1-20.

Brunelli, S. (2018). Audit Reporting for Going Concern Uncertainty: Global Trends and the Case Study of Italy: Springer.

Callen, J. L., \& Fang, X. (2016). Crash Risk and the Auditor-Client Relationship. Contemporary Accounting Research. 
Dunham, K. (2002). Firms that want to switch auditors find it takes time, money and faith. Wall Street Journal Online.

Fleak, S. K., \& Wilson, E. R. (1994). The incremental information content of the goingconcern audit opinion. Journal of Accounting, Auditing \& Finance, 9(1), 149-166.

Francis, J. R. (2011). A framework for understanding and researching audit quality. AUDITING: A Journal of Practice \& Theory, 30(2), 125-152.

Geiger, M. A., \& Raghunandan, K. (2002). Auditor tenure and audit reporting failures. AUDITING: A Journal of Practice \& Theory, 21(1), 67-78.

Ghosh, A., \& Moon, D. (2005). Auditor tenure and perceptions of audit quality. The Accounting Review, 80(2), 585-612.

Gibson, C. H. (2013). Financial reporting and analysis: Using financial accounting information: South-Western Pub.

Hair, J. F., Black, W. C., \& Babin, B. J. (2010). RE Anderson Multivariate data analysis: A global perspective: New Jersey, Pearson Prentice Hall,).

Hay, D., Knechel, W. R., \& Willekens, M. (2014). The Routledge companion to auditing: Routledge.

Jackson, A. B., Moldrich, M., \& Roebuck, P. (2008). Mandatory audit firm rotation and audit quality. Managerial Auditing Journal, 23(5), 420-437.

Knechel, W. R., \& Vanstraelen, A. (2007). The relationship between auditor tenure and audit quality implied by going concern opinions. AUDITING: A Journal of Practice \& Theory, 26(1), 113-131.

Limperg, T. (1985). The social responsibility of the auditor: Limperg Instituut.

Jorjani, M., \& Safari Gerayeli, M. (2018). Auditor tenure and stock price volatility: The moderating role of auditor industry specialization.

Myers, J. N., Myers, L. A., \& Omer, T. C. (2003). Exploring the term of the auditorclient relationship and the quality of earnings: A case for mandatory auditor rotation? The Accounting Review, 78(3), 779-799.

Needles, B. E., Powers, M., \& Crosson, S. V. (2013). Principles of accounting: Cengage Learning.

O'Clock, P., \& Devine, K. (1995). An investigation of framing and firm size on the auditor's going concern decision. Accounting and Business Research, 25(99), 197207.

O'Reilly, D. M. (2009). Do investors perceive the going-concern opinion as useful for pricing stocks? Managerial Auditing Journal, 25(1), 4-16.

Pratoomsuwan, T. (2012). The effect of an audit firm's brand on security pricing. International Journal of Emerging Markets, 7(4), 430-442. 
Soltani, B. (2000). Some empirical evidence to support the relationship between audit reports and stock prices - the French case. International journal of auditing, 4(3), 269-291.

Su, L., Zhao, X., \& Zhou, G. (2015). Auditor tenure and stock price idiosyncratic volatility: The moderating role of industry specialization. AUDITING: A Journal of Practice \& Theory, 35(2), 147-166. 